\title{
PRODUCTION OF PLYWOOD PANEL FOR EXTERIOR USE WITH PARICÁ AND EMBAÚBA TIMBERS ${ }^{1}$
}

João Fábio Machado ${ }^{2 *}$, Éverton Hillig ${ }^{3}$, Luciano Farinha Watzlawick ${ }^{4}$, Ezaquel Bednarczuk ${ }^{2}$ and Everton Lorenzett Tavares ${ }^{2}$

\footnotetext{
${ }^{1}$ Received on 23.08.2017 accepted for publication on 09.08.2018.

${ }^{2}$ Universidade Estadual do Centro-Oeste, Programa de Pós-Graduação em Ciências Florestais, Irati, PR - Brasil. E-mail: <jfmachado1782@gmail.com>,<ziquebednarczuk@yahoo.com.br> and evertontavares1@hotmail.com.

${ }^{3}$ Universidade Estadual do Centro-Oeste, Departamento de Engenharia Florestal, Irati, PR - Brasil. E-mail: $<$ hillig@hotmail.com $>$.

${ }^{4}$ Universidade Estadual do Centro-Oeste, Departamento de Agronomia, Guarapuava, PR - Brasil. E-mail: $<$ farinha@unicenro.br>.

*Corresponding author.
}

\begin{abstract}
This research objective was to evaluate the technical feasibility of using Schizolobium amazonicum Huber ex Ducke (Paricá) and Cecropia palmata Willd (Embaúba) timbers for the production of veneers and external plywood using two types of adhesives: phenol-formaldehyde and tannin-formaldehyde, and different veneer compositions. The trees were harvested in a planted forest area from gap enrichment in the municipality of Dom Eliseu, Pará state. The Pinus elliottii timber was used as the reference and was donated by a company located in the municipality of Irati, Parana state. The panels were produced with pure timber of the three species, and two combinations between the paricá and embaúba species, using a resin weight of $145 \mathrm{~g} \mathrm{~m}^{2}$ in single line. The veneers yield for the paricá was $80.03 \%$ and that of the embaúba $46.37 \%$; The panels produced with pure embaúba timber, or in combination with paricá timber, and bonded with phenol-formaldehyde, presented satisfactory technological properties for external use and were the compositions that presented better properties. The best adhesive for the panels was phenol-formaldehyde, as the tannin-formaldehyde did not present good performance in the weight used in this study.
\end{abstract}

Keywords: Tannin-formaldehyde; Phenol-formaldehyde; Veneers.

\section{PRODUÇÃO DE PAINEL COMPENSADO PARA USO EXTERIOR COM MADEIRAS DE PARICÁ E EMBAÚBA}

\begin{abstract}
RESUMO-Esta pesquisa objetivou avaliar a viabilidade técnica de utilização das madeiras de paricá (Schizolobium amazonicum Huber ex. Ducke) e embaúba (Cecropia palmata Willd) para produção de lâminas de madeira e de painéis compensados de uso externo, utilizando dois tipos de adesivos: fenol-formaldeído e taninoformaldeído, e diferentes composições de lâminas. As árvores de paricá e de embaúba foram coletadas em uma área de floresta plantada a partir do enriquecimento de clareira no município de Dom Eliseu, estado do Pará. A madeira de pinus foi utilizada como testemunha e foi doada por uma empresa situada no municipio de Irati, estado do Paraná. Os painéis foram produzidos com madeiras puras das três espécies, e duas combinações entre as espécies paricá e embaúba, utilizando uma gramatura de cola de $145 \mathrm{~g} / \mathrm{m}^{2} \mathrm{em}$ linha simples. $O$ rendimento em lâminas para o paricá foi de $80,03 \%$ e o da embaúba 46,37\%; Os painéis produzidos com madeira de embaúba pura, ou em combinação com a madeira de paricá, e colados com fenol-formaldeído, apresentaram propriedades tecnológicas satisfatórias para uso exterior eforam as composições que apresentaram melhores propriedades. O melhor adesivo para os painéis foi ofenol formaldeído, pois o tanino-formaldeido não apresentou bom desempenho na gramatura utilizada neste estudo.
\end{abstract}

Palavras-Chave: Tanino-formaldeído; Fenol-formaldeído; Lâminas de madeira. 


\section{INTRODUCTION}

The "paricá" (Schizolobium amazonicum Huber ex. Ducke) is a species native to the Amazon and presents characteristics suitable for veneers and wood panels production. The "embaúba" (Cecropia palmata Willd.) has its occurrence confirmed in the North, Northeast and Central-West Brazil regions (Romaniuc Neto and Gaglioti, 2012). Paricá and Embaúba are species of fast growth, and present potential for industrial activity, especially in the veneers and plywood industry. Almeida et al. (2013) found that, although paricá timber presents lower density than pine, it has superior parallel compression strength.

The paricá timber gives good results in peeling yield. These advantages are cited by Modes et al. (2014) and by Melo et al. (2014) that confirm that the yield of veneers from paricá are even higher than the species traditionally used for this purpose in Brazil, like those of Pinus sp. and Eucalyptus sp.. The Schizolobium amazonicum wood veneers show grayish white coloration, low concentration of extractives, low dimensional stability, low roughness and high wettability (Melo et al., 2013).

There are few studies on the use of "embaúba" timber as a forest raw material, with emphasis in the cellulose production (Heckler et al., 2014) and other types of panels. Iwakiri et al. (2010) verified that the Cecropia hololeuca timber and Schizolobium amazonicum are technically feasible for the production of particleboards and Iwakiri et al. (2012) verified the feasibility of these species for the cement-wood panels' production.

According to Lorenzi (2009), Cecropia glaziovvi presents basic density of $0.41 \mathrm{~g} \mathrm{~cm}^{-3}$, has an straight, cylindrical log, soft to cut, uniform and without ramifications. According to Silva et al. (2012), Cecropia sciadophylla is one of the largest of its kind, its height varies from 10 to $35 \mathrm{~m}$, its log is straight and plump, hollow (fistulous), with smooth bark marked by the scars of the stipules and old petioles.

In Northern Region of Brazil there is difficulty in supplying plywood industries with chemical raw materials, especially phenolic resin, which requires special storage care. In this context, the acacia tannin earns special attention given the ease of transportation and storage, since it can be transported in $50 \mathrm{~kg}$ bags in the powder form.
The objective of this research was to evaluate the technical feasibility of producing plywood for external use with "paricá" and "embaúba" timber, testing different veneers compositions of both species for panel formation and using two types of adhesives in bonding, phenol formaldehyde and tannin-formaldehyde.

\section{MATERIALAND METHODS}

\subsection{Log resources, rotary peeling and yield}

Pine (Pinus elliottii) timber, paricá (Schizolobium amazonicum Huber ex Ducke) and embaúba (Cecropia palmata Willd.) were used, being the first used as a reference because it is a timber species traditionally used in the South Brazil plywood production (Iwakiri et al., 2000). Pinus is a species that is the object of studies for diversified products and including hybrids with other species of the genus (Almeida et al., 2014).

The paricá and embaúba trees came from gap enrichment areas, being the paricá planted and embaúba from natural regeneration, both collected in the Municipality of Dom Eliseu, Pará state. The pine timbers were provided by a company located in Irati municipality, Paraná state. Trees of Paricá and Embaúba, with ages varying between 16 and 19 years were raffling through an inventory map, taking into account a BDH of less than $40 \mathrm{~cm}$, due to the rotary lathes limitation.

After the harvesting, the trees were transformed into logs with $1.74 \mathrm{~m}$ in length and were identified (Figure 1). In this way, the produced veneers were separated by species, trees and logs, and it was also possible to determine the logs amount obtained from each tree.

The timber basic density was determined according to the NBR 11941/2003 standard, using discs removed from the logs ends. The average timber basic density of each tree was calculated according to the method suggested by Melo (2012), weighted by the logs volume between the discs. Also, the evaluation of the logs conicity was carried out, which considered the variation rate of the diameter along their length.

The paricá and embaúba logs were steamed at 42$65^{\circ} \mathrm{C}$ for six hours and processed in a Benecke lathe with traction on the rollers. The pine logs were steamed at a temperature of $60^{\circ} \mathrm{C}$ for 18 hours and processed with Thoms Benato lathe brand spindle system. The veneers were produced with a mean thickness of 1.6 $\mathrm{mm}$ and were identified. 


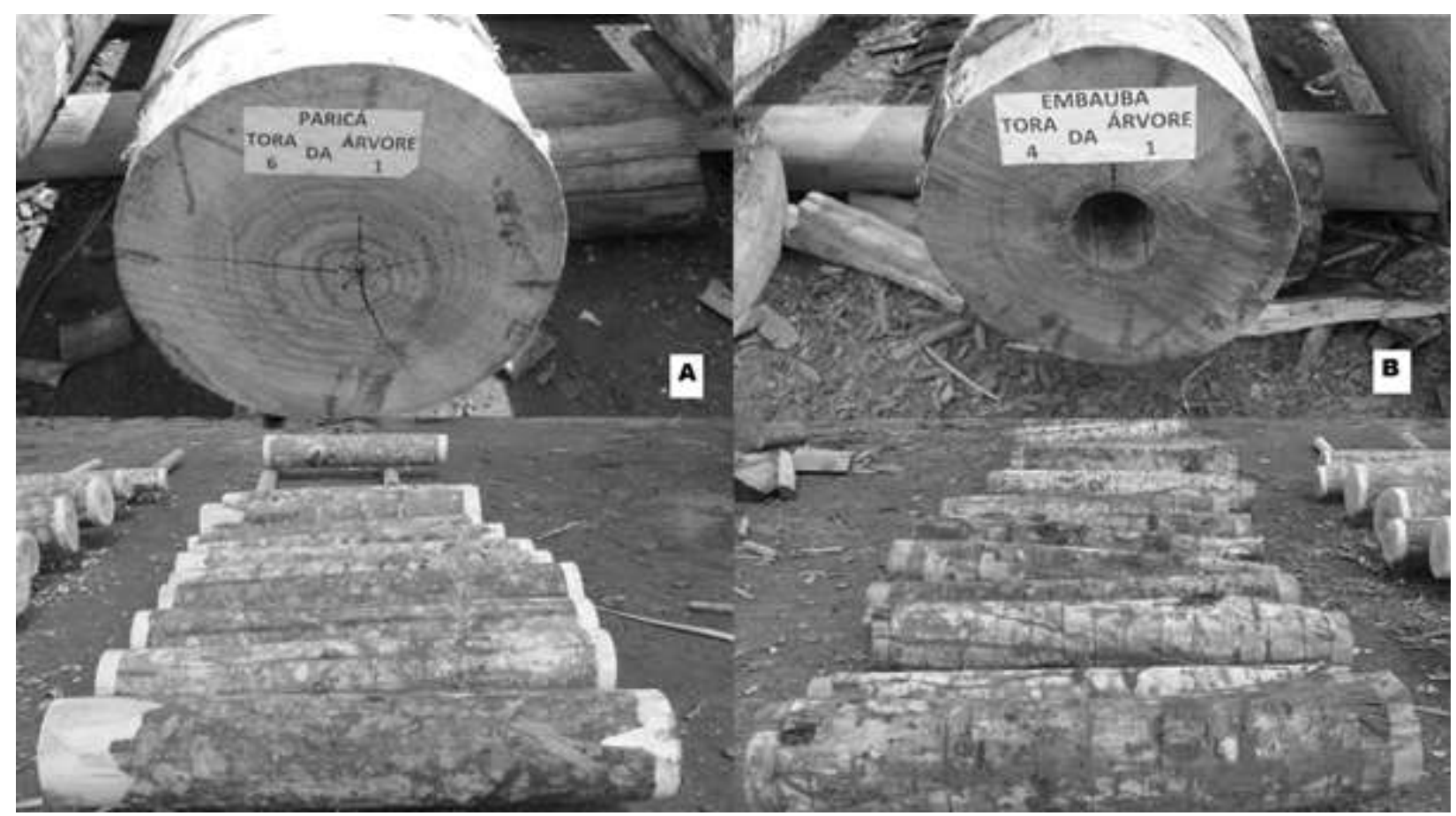

Figure 1 - Identification of logs: paricá (A) and embaúba (B).

Figura 1-Identificação das toras: paricá $(A)$ e embaúba (B).

The peeling yield was determined for the paricá and embaúba logs, using the volume of logs and the volume of veneers obtained, expressed as a percentage. Peeling losses include rounding losses (RL), rollerrest losses (RRL) and miscellaneous losses (ML), which are due to additional operations such as cut, handling and sorting.

\subsection{Experimental design and panel's production}

Plywood panels were produced in the laboratory according to the experimental plan presented in Table 1. Phenol-formaldehyde (FF) and tannin-formaldehyde (TF) resins and five veneers compositions of the three species were used to manufacture the plywood.

The glue mixture of the tannin-formaldehyde resin (PHENOTAN M 50\% solids content) was formulated with $100 \mathrm{~kg}$ resin, $10 \mathrm{~kg}$ wheat flour and $4 \mathrm{~kg}$ paraformaldehyde, resulting in $43.9 \%$ solids content. For phenol-formaldehyde (FF-109-BONARDI with 53\% solids content) the glue mixture formulation was 78 $\mathrm{kg}$ resin, $18.5 \mathrm{~kg}$ wheat flour and $18.5 \mathrm{~kg}$ water, resulting in $35.3 \%$ solids content. $145 \mathrm{~g} \mathrm{~m}^{-2}$ was spread in one surface for both types of adhesives. The panels were
Table 1 - Experimental design.

Tabela 1 - Planejamento experimental.

\begin{tabular}{cccc}
\hline $\begin{array}{c}\text { Veneer } \\
\text { composition }\end{array}$ & Resin & Species & Layers \\
\hline P 1 & & Paricá & 9 \\
P2 & Phenol- & Embaúba & 9 \\
P3 & Pine & 9 \\
P4 & formaldehyde & Paricá/Embaúba & $5 / 4$ \\
P5 & & Embaúba/Paricá & $5 / 4$ \\
\hline P6 & & Paricá & 9 \\
P7 & Tannin- & Embaúba & 9 \\
P8 & formaldehyde & Pine & 9 \\
P9 & & Paricá/Embaúba & $5 / 4$ \\
P10 & & Embaúba/Paricá & $5 / 4$ \\
\hline
\end{tabular}

pressed at $12 \mathrm{kgf} \mathrm{cm}^{-1}, 130^{\circ} \mathrm{C}$ and for a time of $1 \mathrm{~min}$ $\mathrm{mm}^{-1}$. Afterwards, they were rested for 25 days until stabilized and then cut squared.

\subsection{Properties evaluated and statistical analysis}

The properties analyzed were: panels thickness, apparent density, moisture content, water absorption, swelling, MOE and MOR in static bending (parallel and perpendicular) and bonding quality (glue line shear strength - GS and wood failure - WF - under boiling 
conditions), according to the standards NBR 9485/ 11, NBR 9484/11, NBR 9486/11, NRB 9535/11, NBR 9533/ 11, NBR ISO 12466/1: 2006, NBR ISO 12466/2: 2006.

For analysis of the timber basic density, the weighted averages of each species were determined and submitted to analysis of variance and Tukey's test. The peeling yield was analyzed by subjecting the variables to the $\mathrm{T}$ test for independent samples. The analysis of the panels' physical and mechanical properties was carried out in two stages: first the means were determined by type of panel produced, and their properties were compared with the requirements established by ABIMCI (2007) for commercial panels. In a second step, a factorial ANOVA was performed, considering the type of adhesive and veneers composition, to evaluate these factors in the properties of the panels. All statistical analysis was performed at $95 \%$ probability.

\section{RESULTS}

\subsection{Timber basic density and peeling yield}

The average timber basic density of the species studied was $0.42 \mathrm{~g} \mathrm{~cm}^{-3}, 0.28 \mathrm{~g} \mathrm{~cm}^{-3}$ and $0.37 \mathrm{~g} \mathrm{~cm}^{-3}$, respectively for pine, paricá and embaúba. Statistical analysis showed that the basic density of embaúba timber was not different from that of pine, while that of paricá was lower than both. Table 2 shows the variables that express the peeling yield for the paricá and embaúba timbers.

\subsection{Panels properties}

The mean values of the evaluated properties from the panels, separated by panel type, are shown in Table 3. For GS and WF, average values for the panels of veneers compositions 6 to 10 (glued with tannin-formaldehyde) are not presented, since samples were delaminated (under

Table 2 - Data of $\log$ dimensions and peeling yield variables. Tabela 2-Dados de dimensões das toras evariáveis de rendimento do processo de laminação.

\begin{tabular}{lcccccc}
\hline Species & $\begin{array}{c}\mathrm{MD} \\
(\mathrm{cm})\end{array}$ & $\begin{array}{c}\mathrm{CON}) \\
\left(\mathrm{cm} \mathrm{m}^{-1}\right)\end{array}$ & $\begin{array}{c}\mathrm{PY} \\
(\%)\end{array}$ & $\begin{array}{c}\mathrm{RRL} \\
(\%)\end{array}$ & $\begin{array}{c}\mathrm{RL} \\
(\%)\end{array}$ & $\begin{array}{c}\mathrm{ML} \\
(\%)\end{array}$ \\
\hline Paricá & 29.89 & 0.88 & 80.03 & 6.73 & 6.00 & 7.03 \\
Embaúba & 26.83 & 1.47 & 46.37 & 25.37 & 9.37 & 18.90 \\
$\mathrm{~T}$ calc & $1.10^{\text {ns }}$ & $2.04^{\text {ns }}$ & $-8.17^{* *}$ & $5.08^{* *}$ & $1.78^{\text {ns }}$ & $4.42^{*}$ \\
$\mathrm{P}(\mathrm{T}<=\mathrm{t})$ & 0.3312 & 0.1115 & 0.0012 & 0.0071 & 0.1499 & 0.0115 \\
\hline
\end{tabular}

Notes: T calc: calculated by the $\mathrm{T}$ test for independent samples; MD: mean diameter; CON: conicity; PY: peeling yield without bark; RRL: rest roll losses; RL: rounding losses; ML: miscellaneous losses; ns: not significant; *: significant at $95 \%$; **: significant at $99 \%$.

Revista Árvore. 2018;42(4):e420406 boiling conditions) and the test could not be performed.

Table 4 shows the results of the average values factorial analysis of water absorption; swelling; MOR and MOE in static bending, parallel and perpendicular; glue line shear strength and wood failure, for each level of factor studied.

\section{DISCUSSION}

\subsection{Timber basic density and peeling yeld}

The average basic density determined for the timber of Amazonian hardwood species was similar to that verified by other researchers. For paricá, Almeida (2009) verified basic density of $0.28 \mathrm{~g} \mathrm{~cm}^{-3}$ and Almeida et al. (2013) of $0.30 \mathrm{~g} \mathrm{~cm}^{-3}$. Heckler et al. (2014) found an average value of $0.39 \mathrm{~g} \mathrm{~cm}^{-3}$ when evaluating the basic density of nine embaúba trees.

In general, the species used for veneers production and for external panels have timber basic density between 0.4 and $0.5 \mathrm{~g} \mathrm{~cm}^{-3}$. In this way, the embaúba timber presents itself with advantage in relation to paricá timber.

It was verified that the logs conicity of the paricá and embaúba species were relatively small and there was no statistical difference between the average values of each species. This fact is explained by the trees logs, approximately cylindrical and straight.

The average peeling yield for paricá timber (80.03\%) was considered high in relation to the results obtained by other researchers for the same species. Modes et al. (2014) found an average yield of $71.83 \%$ and Melo et al. (2014) found a yield of $59.92 \%$, both using the same type of lathe. This was attributed to the pre-treatment applied to the logs, which reduced the handling losses due to the greater veneers malleability.

For embaúba the peeling yield was lower, mainly due to roller-rest losses and miscellaneous losses. The average loss with roller-rest of $25.37 \%$ was due to occurrence of the hollow in the all logs central region of this species. The miscellaneous losses, larger than the paricá timber, demonstrate that the six hours steam at a temperature between 42-65 ${ }^{\circ} \mathrm{C}$ was more effective for paricá.

\subsection{Panels properties}

The average thickness of the tannin-formaldehyde panels varied from 13.05 to $14.05 \mathrm{~mm}$ and that of phenolformaldehyde panels from 12.63 to $13.96 \mathrm{~mm}$. The higher initial viscosity of the tannin glue impaired its penetration 
Table 3 - Mean values by veneer composition of the panel's properties. Tabela 3 - Valores médios das propriedades por composição do painel.

\begin{tabular}{|c|c|c|c|c|c|c|c|c|c|c|c|}
\hline$\overline{\mathrm{VC}}$ & $\begin{array}{c}\mathrm{T} \\
(\mathrm{mm})\end{array}$ & $\begin{array}{l}\text { Dens. } \\
\left(\mathrm{g} \mathrm{m}^{\prime \prime 3}\right)\end{array}$ & $\begin{array}{l}\text { MC } \\
(\%)\end{array}$ & $\begin{array}{l}\text { WA } \\
(\%)\end{array}$ & $\begin{array}{c}\mathrm{S} \\
(\%)\end{array}$ & $\begin{array}{r}\mathrm{MOR \perp} \\
(\mathrm{MPa})\end{array}$ & $\begin{array}{l}\mathrm{MOR} / / \\
(\mathrm{MPa})\end{array}$ & $\begin{array}{l}\mathrm{MOE} \perp \\
(\mathrm{MPa})\end{array}$ & $\begin{array}{l}\mathrm{MOE} / / \\
(\mathrm{MPa})\end{array}$ & $\begin{array}{c}\mathrm{GS} \\
(\mathrm{MPa})\end{array}$ & $\begin{array}{l}\text { WF } \\
(\%)\end{array}$ \\
\hline$\overline{\mathrm{P} 1}$ & 12.63 & 0.40 & 13.01 & 86.3 & 6.5 & 24.70 & 34.93 & 3167 & 4915 & 0.9 & 77 \\
\hline P2 & 13.75 & 0.47 & 12.06 & 71.5 & 5.4 & 29.23 & 47.52 & 3327 & 7186 & 1.2 & 70 \\
\hline P3 & 13.96 & 0.57 & 12.99 & 66.4 & 7.0 & 25.68 & 39.50 & 2199 & 3784 & 1.3 & 55 \\
\hline P4 & 13.83 & 0.43 & 12.72 & 78.3 & 6.3 & 32.53 & 34.82 & 4082 & 5585 & 1.0 & 53 \\
\hline P5 & 13.24 & 0.45 & 12.25 & 69.0 & 6.2 & 28.90 & 42.53 & 3314 & 6352 & 1.0 & 51 \\
\hline P6 & 13.49 & 0.39 & 12.89 & 76.5 & 7.8 & 23.97 & 29.32 & 3051 & 5111 & - & - \\
\hline P7 & 13.05 & 0.49 & 11.69 & 65.7 & 6.5 & 27.75 & 46.88 & 3324 & 7614 & - & - \\
\hline P8 & 13.90 & 0.53 & 12.88 & 75.5 & 6.8 & 22.65 & 34.63 & 1901 & 3386 & - & - \\
\hline P9 & 14.05 & 0.42 & 11.63 & 73.0 & 7.8 & 31.63 & 31.15 & 4094 & 5044 & - & - \\
\hline P10 & 13.38 & 0.45 & 11.68 & 65.4 & 6.5 & 23.44 & 42.72 & 2940 & 6876 & - & - \\
\hline $\mathrm{CV}$ & 1.88 & 4.61 & 12.19 & 7.79 & 14.0 & 12.04 & 11.27 & 11.22 & 9.87 & 22.3 & 23.3 \\
\hline
\end{tabular}

Notes: VC: veneers compositions; T: panels thickness; Dens.: apparent density; MC: moisture content; WA: water absorption; S: swelling; MOR: modulus of rupture; MOE: modulus of elasticity; //: parallel direction; $\perp$ : perpendicular direction; GS Glue line shear strength; WF: wood failure.

Table 4 - Influence of the adhesive type and the veneers composition on the panels properties. Tabela 4 - Influência do tipo de adesivo e da composição de lâminas nas propriedades dos painéis.

\begin{tabular}{|c|c|c|c|c|c|c|c|c|c|}
\hline Factor & Level & $\begin{array}{l}\text { WA } \\
(\%)\end{array}$ & $\begin{array}{c}\mathrm{S} \\
(\%)\end{array}$ & $\begin{array}{r}\mathrm{MOR} \perp \\
(\mathrm{MPa})\end{array}$ & $\begin{array}{c}\mathrm{MOR} / / \\
(\mathrm{MPa})\end{array}$ & $\underset{(\mathrm{MPa})}{\mathrm{MOE \perp}}$ & $\begin{array}{c}\mathrm{MOE} / / \\
(\mathrm{MPa})\end{array}$ & $\begin{array}{c}\mathrm{GS} \\
(\mathrm{MPa})\end{array}$ & $\begin{array}{l}\text { WF } \\
(\%)\end{array}$ \\
\hline & $\mathrm{FF}$ & $74.3 \mathrm{a}$ & $6.3 b$ & $28.2 \mathrm{a}$ & $39.9 a$ & $3218 \mathrm{a}$ & $5565 a$ & 1.1 & 61 \\
\hline Adhesive & $\mathrm{TF}$ & $71.3 \mathrm{a}$ & $7.1 \mathrm{a}$ & $25.9 b$ & $36.9 \mathrm{~b}$ & $3063 a$ & $5606 \mathrm{a}$ & - & - \\
\hline \multirow{5}{*}{ Composition } & $\mathrm{Pa}$ & $81.4 a$ & $7.1 \mathrm{a}$ & $24.3 \mathrm{c}$ & $32.1 \mathrm{~b}$ & $3110 \mathrm{~b}$ & $5013 c$ & $0.9 \mathrm{a}$ & $77 a$ \\
\hline & Em & $68.6 b$ & $6.0 \mathrm{a}$ & $28.5 \mathrm{ab}$ & $47.2 \mathrm{a}$ & $3326 b$ & $7400 a$ & $1.2 \mathrm{a}$ & $70 \mathrm{ab}$ \\
\hline & $\mathrm{Pi}$ & $71.0 \mathrm{~b}$ & $6.9 \mathrm{a}$ & $24.2 \mathrm{c}$ & $37.1 \mathrm{~b}$ & $2050 \mathrm{c}$ & $3585 d$ & $1.3 \mathrm{a}$ & $55 \mathrm{ab}$ \\
\hline & $\mathrm{Pa} / \mathrm{Em}$ & $75.7 \mathrm{ab}$ & $7.0 \mathrm{a}$ & $32.1 \mathrm{a}$ & $33.0 \mathrm{~b}$ & $4988 a$ & $5315 c$ & $1.0 \mathrm{a}$ & $53 \mathrm{ab}$ \\
\hline & $\mathrm{Em} / \mathrm{Pa}$ & $67.2 \mathrm{~b}$ & $6.3 \mathrm{a}$ & $26.2 \mathrm{bc}$ & $42.7 \mathrm{a}$ & $3127 \mathrm{~b}$ & $6613 b$ & $1.0 \mathrm{a}$ & $52 \mathrm{~b}$ \\
\hline Interaction & Fcalc & $2.4^{\mathrm{ns}}$ & $1.5^{\mathrm{ns}}$ & $1.1^{\mathrm{ns}}$ & $1.1^{\mathrm{ns}}$ & $2.3^{\mathrm{ns}}$ & $2.3^{\mathrm{ns}}$ & & \\
\hline
\end{tabular}

Notes: WA: water absorption; S: swelling; MOR: modulus of rupture; MOE: modulus of elasticity; //: parallel direction; $\perp$ : perpendicular direction; GS Glue line shear strength; WF: wood failure. *: Significant at 95\% probability; Ns: not significant at 95\% probability; Means followed by same letter do not differ by test " $F$ " or Tukey test at $95 \%$ probability.

into the wood structure and contributed to the formation of a thicker glue line, with a tendency to increase the thickness of the panel.

The results for apparent density varied from 0.40 to $0.57 \mathrm{~g} \mathrm{~cm}^{-3}$ for panels with phenol-formaldehyde adhesive and from 0.38 to $0.53 \mathrm{~g} \mathrm{~cm}^{-3}$ for the panels with tanninformaldehyde. For panels of $12 \mathrm{~mm}$ and five veneers pine, ABIMCI (2007) establishes a minimum density limit of $0.476 \mathrm{~g} \mathrm{~cm}^{-3}$, so the panels of veneers composition P1, P4, P5, P6, P9 and P10 were of lower densities.

Iwakiri et al. (2011) found low densities for plywood produced with paricá, of $0.345-0.394 \mathrm{~g} \mathrm{~cm}^{-3}$. In this study, the values obtained for the paricá panels presented an average density of $0.40 \mathrm{~g} \mathrm{~cm}^{-3}$ and the veneers of this species contributed to a lower density of the mixed panels in comparison to those of embaúba and pine.

All panels with phenol-formaldehyde adhesive had moisture content greater than $12 \%$ and the panels P7, P9 and P10, with tannin-formaldehyde adhesive, they were below the limit of $12 \%$ suggested by ABIMCI (2007).

Regarding the static bending, all values presented are within the minimum and maximum limits, in both the parallel and the perpendicular directions, as suggested by ABIMCI (2007).

Comparing the GS and WF values of the panels with the values suggested by ABIMCI (2007) for panels of 12 $\mathrm{mm}$, the presented values are between the maximum and minimum limits, except for the panels with tanninformaldehyde, that it was not possible to carry out the test (under boiling conditions) due to its delamination.

\subsection{Factorial analysis of adhesive type and veneers composition}

The different adhesives did not present statistical differences for the water absorption values. Regarding the veneers compositions, it can be observed that the panels differed statistically and there was no interaction between 
the factors. The panels produced with paricá on the veneers' face absorbed more water when compared with the others, and this fact is related to the lower density of paricá timber and greater veneers' porosity.

The tannin-formaldehyde panels showed the highest swelling. This fact, even with the panels without absorbed more water, shows that the tannin bonding did not provide the same efficiency as the phenol, with respect to contain the liberation of internal panel stresses produced during pressing. There were no differences in swelling between the panels produced with different veneers compositions and the interaction was not significant.

The bending strength $\left(\mathrm{MOR}^{\perp}\right.$ and $\left.\mathrm{MOR} \backslash\right)$ was higher for phenol-formaldehyde panels. Regarding the compositions, there was greater bending strength of the plywood produced with embaúba or in the embaúba / paricá composition, both in $\mathrm{MOR}^{\perp}$ and $\mathrm{MOR} \backslash$, demonstrating that this species' veneers contributed to increase the panel resistance. It was also verified that the panels produced with paricá or with the paricá / embaúba combination had bending strength similar to the panels of pine, even though this species' veneers come from a timber of lower density.

The bending stiffness of the panels $\left(\mathrm{MOE}^{\perp}\right.$ and MOE $\backslash$ ) followed a tendency similar to the variation presented by their strength, however, especially the panels produced with paricá veneers, that even presented greater stiffness than panels produced with pine veneers.

The panels of paricá / embaúba veneers composition presented mean values of $\mathrm{MOR}^{\perp}$ similar to the mean values in the MOR $\backslash$, demonstrating that this is the best combination for the bending strength properties balance of the plywood. The same panels presented higher values of $\mathrm{MOR}^{\perp}$ than the other composition. Despite the greater number of paricá veneers in this panel composition, the embaúba veneers occupied the parallel position to the applied effort and this increased the panel perpendicular bending strength.

The glue line shear strength of the core veneers, after boiling, which was only applied to the phenol-formaldehyde panels, was not influenced by the veneers composition. For wood failures, a statistical difference was found only between the panels produced only with paricá veneers and the embaúba / paricá combination, which presented lower mean values. In general, there were higher wood failure values for the paricá veneers, attributed to the lower timber density of this species.

\section{CONCLUSIONS}

Based on the results analysis obtained through this research it is possible to present the following conclusions:

Paricá timber presented the lowest basic density $\left(0.28 \mathrm{~g} \mathrm{~cm}^{-3}\right)$, and the embaúba timber $\left(0.37 \mathrm{~g} \mathrm{~cm}^{-3}\right)$ and pinus $\left(0.42 \mathrm{~g} \mathrm{~cm}^{-3}\right)$ did not differ statistically.

The peeling yield was 80.03 and $46.37 \%$ for the paricá and embaúba timbers, respectively. The largest loss in the peeling process for embaúba species, of $25.37 \%$, was the losses per roll-rest, due to the hollow in the log central region. The miscellaneous losses for the embaúba wood, of $18.90 \%$, and rounding, of $9.37 \%$, were attributed to the physical characteristics of the species and the greater log conicity.

The phenol-formaldehyde panels reached the minimum values required by ABIMCI for commercial panels of $12 \mathrm{~mm}$ and five veneers pine, and the adhesion requirements for panels of exterior use. The tanninformaldehyde adhesive did not present good performance at the weight used in this study.

Embaúba timber has demonstrated its potential for individual use or in combination with Paricá veneers in the manufacture of exterior plywood, providing greater mechanical resistance to the panel when used on the face and greater mechanical stability when used in the core. For the development of future research, it is suggested the performance evaluation of the panels under use conditions.

\section{ACKNOWLEDGEMENTS}

The authors thank the companies: AZF compensados, FV de Araújo and ADECO compensados for the collaboration.

\section{REFERENCES}

Associação Brasileira da Indústria de Madeira Processada Mecanicamente - ABIMCI. Painéis compensados de pinus. Catálogo Técnico, Curitiba, 2007, 4p.

Almeida NF, Bortoletto Jr G, Mendes RF, Surdi PG. Produção e Avaliação da Qualidade de Lâminas de Madeira de um Híbrido de Pinus elliottii var. elliottii $\times$ Pinus caribaea var. hondurensis. Floresta e Ambiente. 2014;21(2):261-8. 
Almeida DH, Scaliante RM, Macedo LB, Macêdo NA, Dias AA, Christoforo AL, et al. Caracterização completa da madeira da espécie amazônica paricá (Schizolobium amazonicum Herb) em peças de dimensões estruturais. Revista Árvore.2013;37(6):1175-81.

Almeida VC. Efeito da adição de carga extensora nas propriedades do adesivo uréia formaldeído e dos compensados de pinus e paricá.

[dissertação]. Viçosa, Minas Gerais: Universidade Federal de Viçosa; 2009. 86p.

Heckler C, Sansígolo CA, Manente FG, Basso S. Densidade básica da madeira de Cecropia $\mathrm{sp.}$ (embaúba) e sua influência na produção de celulose kraft. Revista Científica Eletrônica de Engenharia Florestal. 2014;23(1):11-9.

Iwakiri S, Nielsen IR, Alberti RAR. Avaliação da influência de diferentes composições de lâminas em compensados estruturais de Pinus elliottii e Eucalyptus saligna. Cerne. 2000;6(2):19-24.

Iwakiri S, Zeller F, Pinto JÁ, Ramirez MGL, Souza MM, Seixas R. Avaliação do potencial de utilização da madeira de Schizolobium amazonicum "Paricá" e Cecropia hololeuca "Embaúba" para produção de painéis aglomerados. Acta Amazônica, 42(2):2010.303-8.

Iwakiri S, Vargas CA, Parchen CFA, Weber C, Batista CC, Garbe EA, et al. Avaliação da qualidade de painéis compensados produzidos com lâminas de madeira de Schizolobium amazonicum. Floresta. 2011;41(3):451-8.

Iwakiri S, Silva LS, Trianoski R, Bonduelle GM,
Rocha VY. Avaliação do potencial de utilização da madeira de Schizolobium amazonicum "Paricá" e Cecropia hololeuca "Embaúba" para produção de painéis cimento-madeira. Cerne. 2012;18(2):303-8.

Lorenzi H. Árvores Brasileiras: manual de identificação e cultivo de plantas arbóreas nativas do Brasil. v.3. São Paulo: Instituto Plantarum; 2009.384p.

Melo RR, Del Menezzi CHS, Souza MR, Stangerlin DM. Avaliação das propriedades físicas, químicas, mecânicas e de superfície de lâminas de paricá (Schizolobium amazonicum Huber ex. Ducke). Floresta e Ambiente. 2013;20(2):238-49.

Melo RR, Del Menezzi CHS, Pavan BE, Rodolfo Junior F. Rotary peeling yield of Schizolobium amazonicum (Leguminosae - Caesalpinioideae). Acta Amazônica. 2014;44(3):315-20.

Modes KS, Bortoleto Júnior G, Santos LMH, Bento AR, Vivian MA. Rendimento em laminação da madeira de Schizolobium amazonicum em torno desfolhador do tipo tracionado. Ciência da Madeira. 2014;5(2):151-7.

Romaniuc Neto S, Gaglioti AL. Urticaceae. In: Lista de espécies da flora do Brasil. Rio de Janeiro: Instituto de Pesquisa do Jardim Botânico do Rio de Janeiro; 2012.

Silva RCVM, Gaglioti AL, Carvalho LT, Gomes JI, Margalho L. Conhecendo espécies de plantas da Amazônia: imbaubão (Cecropia sciadophylla Mart. - Urticaceae). Belém: Embrapa; 2012. (Comunicado Técnico, 234) 